Revista de la red interuniversitaria de estudios sobre las literaturas rioplatenses contemporáneas en Francia

$18 \mid 2018$

El río y la ciudad

\title{
Cuadernos del Tigre
}

Daniel Samoilovich y Eduardo Stupía

\section{OpenEdition}

Journals

Edición electrónica

URL: https://journals.openedition.org/lirico/5537

DOI: 10.4000/lirico.5537

ISSN: 2262-8339

Editor

Réseau interuniversitaire d'étude des littératures contemporaines du Río de la Plata

\section{Referencia electrónica}

Daniel Samoilovich y Eduardo Stupía, «Cuadernos del Tigre», Cuadernos LIRICO [En línea], 18 | 2018

Publicado el 05 octubre 2018, consultado el 08 junio 2021. URL: http://journals.openedition.org/lirico/ 5537 ; DOI: https://doi.org/10.4000/lirico.5537

Este documento fue generado automáticamente el 8 junio 2021.

\section{(c) (i) (9)}

Cuadernos LIRICO está distribuido bajo una Licencia Creative Commons Atribución-NoComercialSinDerivar 4.0 Internacional. 


\section{Cuadernos del Tigre}

Daniel Samoilovich y Eduardo Stupía

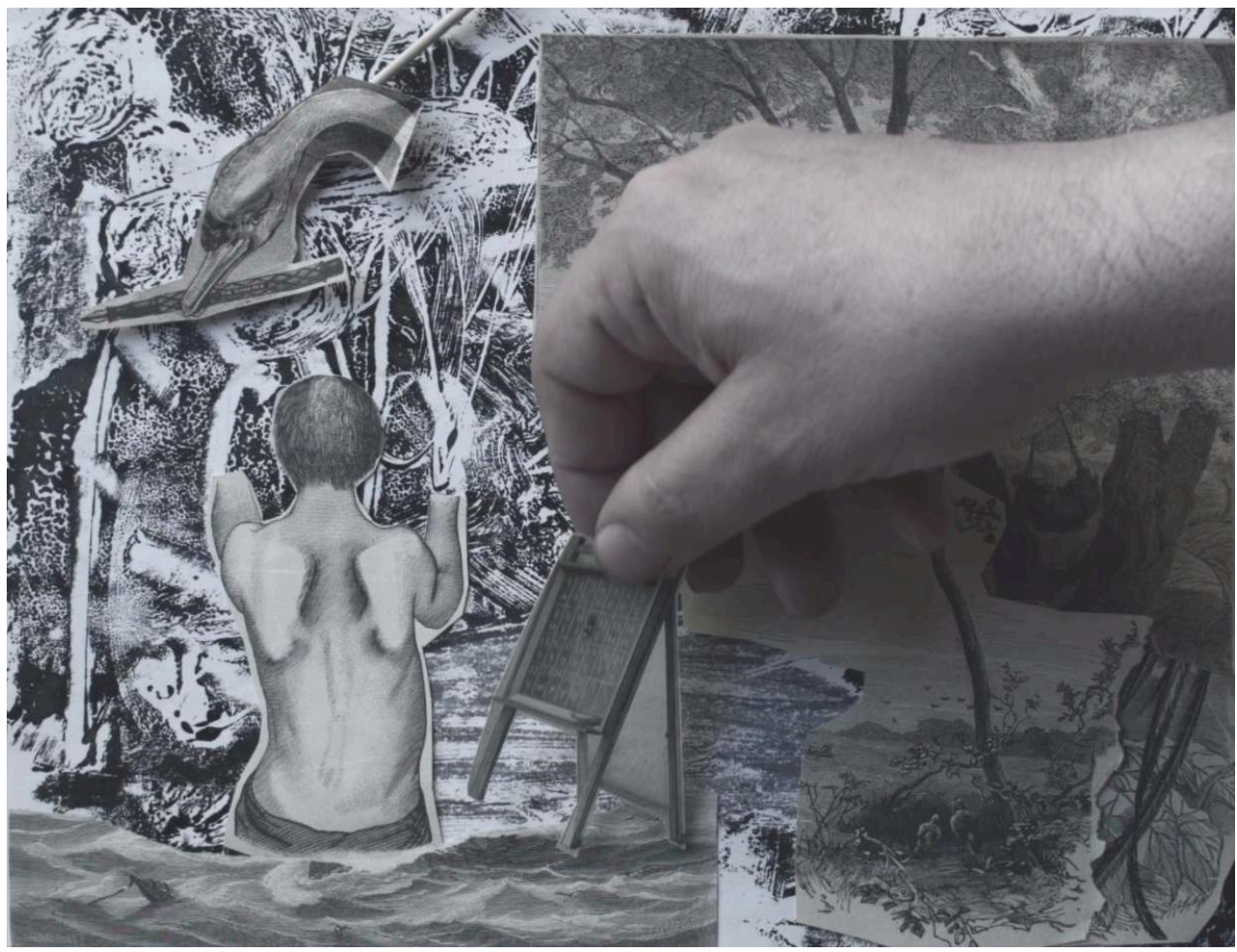

Ver documento anexo. 